\title{
Metamorphic conditions of the omphacite-garnet gneiss from Otrøy, Western Gneiss Region, Scandinavian Caledonides
}

\author{
Johanna Holmberg ${ }^{1}$, Jarosław Majka ${ }^{1,2}$, Iwona Klonowska ${ }^{1}$ \\ ${ }^{1}$ Uppsala University, Uppsala, Sweden, e-mail: holmberg.johanna0921@gmail.com \\ ${ }^{2}$ AGH University of Science and Technology, al. A. Mickiewicza 30, 30-059 Krakow, Poland
}

(C) 2016 Authors. This is an open access publication, which can be used, distributed and reproduced in any medium according to the Creative Commons CC-BY 4.0 License requiring that the original work has been properly cited.

The Western Gneiss Region (WGR) is one of the Earth's most studied ultra-high pressure (UHP) terranes. It consists of continental crustal rocks that host e.g. coesite-bearing eclogites and diamond-bearing garnet-pyroxenites. These self-evident high pressure lithologies naturally attract most of the attention, whereas their host rocks are not studied in much detail. In this study we examined, eclogite- and peridotite-hosting, garnet-omphacite gneisses from the island of Otrøy situated in the WGR (Norway, Scandinavian Caledonides), to deliver pressure-temperature conditions of their formation. High pressure mineral assemblage including e.g. omphacite and phengite together with assumed pseudomorphs after coesite located in omphacite and garnet suggest formation of the studied rocks under ultrahigh pressure metamorphic (UHP) conditions. However, geothermobarometry based on (a) the garnet-clinopyroxene $\mathrm{Fe}-\mathrm{Mg}$ exchange reaction and (Ravna 2000), and (b) the net-transfer reaction 6 diopside +3 muscovite $=3$ celadonite +2 grossular + pyrope (Ravna \& Terry 2004) yielded pressure-temperature conditions of c. $880^{\circ} \mathrm{C}$ and $2.2 \mathrm{GPa}$, characteristic for just high pressure metamorphism, but not in the stability field of coesite (hence not
UHP conditions). It might be an effect of partial re-equilibration of the mineral system used for geothermobarometry. Such re-equilibration could have happened during the decompression stage, which followed the metamorphic peak. Therefore alternative pressure-temperature estimates using e.g. phase equilibrium thermodynamic modeling or Raman band shift based geothermobarometry are needed to cross-check the results obtained using the conventional technique. Nevertheless, it is already evident that the Otrøy gneisses were formed due to the deep subduction of continental crust during the Scandian collision between the continents Baltica and Laurentia that resulted in the final closure of the Iapetus Ocean in the early Devonian.

\section{REFERENCES}

Ravna E.J.K., 2000. The garnet-clinopyroxene geothermometer - an updated calibration. Journal of Metamorphic Geology, 18, 211-219.

Ravna E.J.K. \& Terry M.P., 2004. Geothermobarometry of UHP and HP eclogites and schists - an evaluation of equilibria among garnet-clinopyroxene-kyanite-phengite-coesite/quartz. Journal of Metamorphic Geology, 22, 579-592. 